\title{
Rare Books at Harvard
}

Mr. Jackson holds the posts of assistant librarian in charge of rare books and professor of bibliography at Harvard University and has been in charge of the Houghton Library since its opening in the spring of $I 94 I$.

$\mathrm{T}$ HE воOKS which Sir Kenelm Digby gave Harvard College in 1655 were all, with one exception, unhappily burned in the fire of 1764 . From the list of them which has come down to us they were apparently rather solid, patriotic tomes, which very likely were bound in the same handsome calf or morocco, decorated with his cipher, as were the books which he gave to the Bodleian or those which occur occasionally on the market from his library, seized by the King of France on his death. If we trace the vicissitudes through which the single surviving volume has passed, we may have some notion of the reasons for the changing means by which the more valuable books belonging to the college have been protected.

In 1667 the first set of "Rules for the Library Keeper" provided "There shall be no lending or removing out of the Library the new Globes or books of extraordinary vallue but with very great caution \& upon extraordinary occasion." Whether at that time such books were segregated or especially marked we do not know, but later we learn that at the annual inspection of the Visiting Committee "prohibited" books were removed from their closet and put on the shelves in their places for the day.
Furthermore, in 1764 , when Nathaniel Hurd made Harvard's first bookplate, some copies were struck off with red ink to be affixed to the books of special value.

Until I 840, when Gore Hall was completed, the major dangers from which Harvard's books needed to be protected were fire, theft, careless handling, binders' knives, and the fortunes of war. The losses suffered in the fire of 1764 are well known; losses of the more valuable books, or rather of what then were considered the more valuable, by theft or careless handling were presumably kept to a minimum by the "closet" system. The binders, however, were a more serious hazard. The leather which they used was evidently a local product, and their handiwork, while pleasant in appearance, has not generally been as long lasting as most European bindings of the same period. In the case of the surviving Digby volume, which apparently was rebound about I8oo, not only have the hinges cracked but, far worse, the motto and signature of the donor, written at the top of the title page, have been badly cropped. One cannot forbear suspecting that the original Digby binding might have been repaired with proper care and materials. Finally, we now have no means of knowing what may have been the losses and damage suffered when in I 775 the library was dismantled and removed to Concord and Andover.

Gore Hall with its extensions and "modern improvements," together with the growth and industrialization of Cam- 


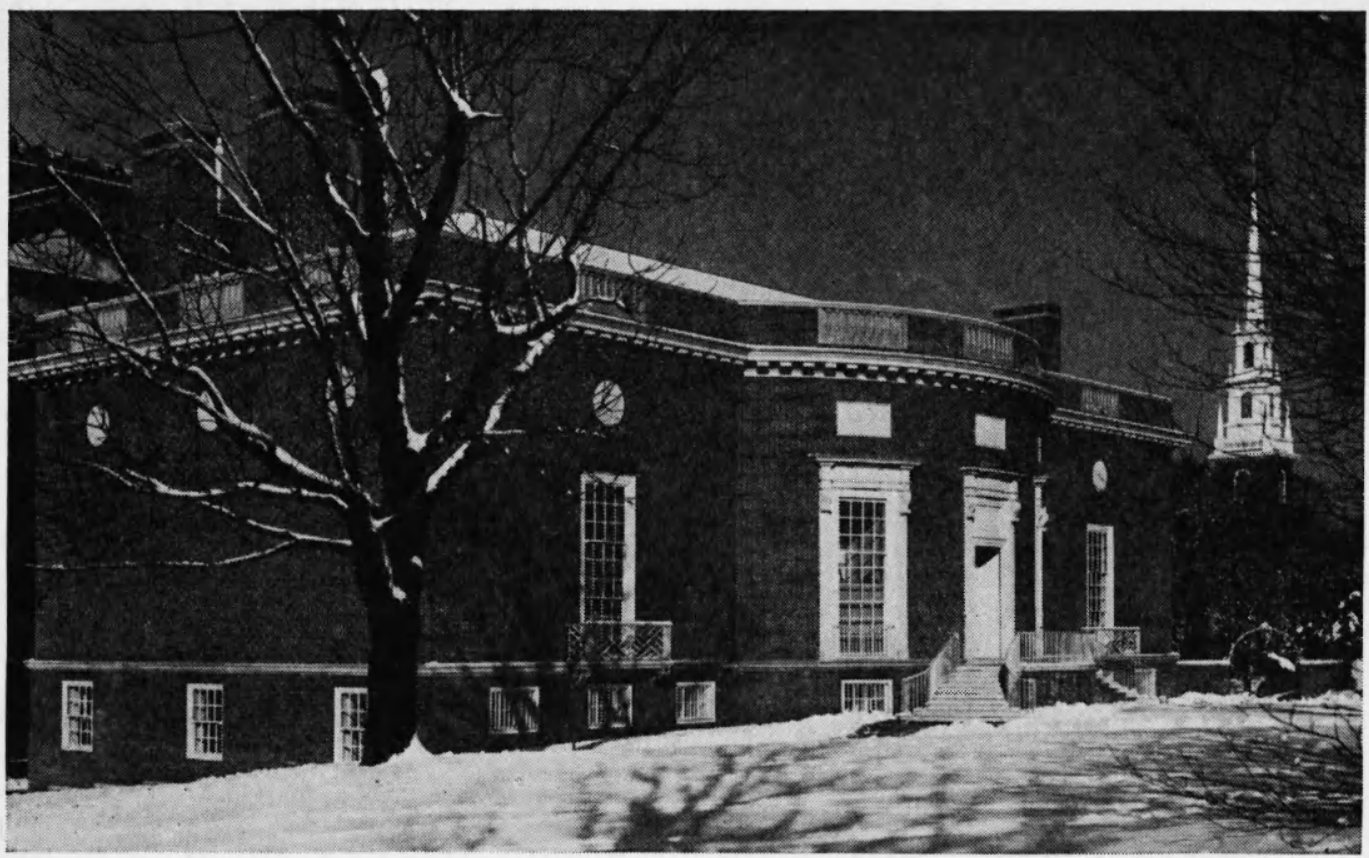

Houghton LibraRy

bridge, presented new problems and hazards. Although a fireproof building according to the standards of that day, it had been rather cheaply constructed, with more attention to external architecture than to solidity and soundness. For example, it had only single walls which permitted condensation and moisture, a condition to which previously Harvard's books had not been subjected and of which all too many volumes testify that Librarian Sibley's complaints on that score were more than justified. The cast-iron stacks which were erected in the addition of 1875 and of which some remnants remain in the $\mathrm{Mu}$ seum of Comparative Zoölogy, were of ornamental, Victorian design and prickly with projections, bolts, and roughnesses which were not entirely eliminated from Harvard's shelving until the erection of the stacks described below. It is nearly miraculous, for example, that a large-paper set of Walton's Polyglot in fine contemporary morocco, recently transferred from open stacks, has survived almost unscratched.

\section{Atmospheric Conditions}

Far more dangerous, however, were the introduction of steam heat in 1875 and the dirt and atmospheric acids which are a concomitant of modern city life-the Chamber of Commerce now describes Cambridge as the third industrial city of New England. The steam heat reduced still further the low humidity normal to a New England winter and increased the variation between the dryness of winter and the dampness of summer, with only too evident deterioration and warping of leather and vellum bindings. Until the introduction of central heat, the conditions in the Harvard library in this respect presumably were not much different from 
those obtaining in a European country house. The polluted air aided in the disintegration of the bindings and, even more serious, of the paper and ink. The damage caused by this condition is often diffcult to measure and, indeed, varies greatly according to the chemical composition of the paper. While many of the oldest books show little signs of deterioration, there are large numbers of seventeenth century Central European books and some popular literature of all countries from the earliest times, of which the paper is badly discolored and weak. This is, of course, due more to the poor quality of the paper used than to the acids in the air, but if these books, and a large portion of the books of the last hundred years which we or posterity may consider most valuable, are to be preserved at all, it must be under conditions which will protect the paper from all harmful agents.

The provisions made for the care of rare books in the Harry Elkins Widener Memorial Library, which was completed in 1915, with one exception, differed only in size from those of Gore Hall. For the first time, a special reading room was provided where the books and manuscripts could be consulted under supervision. There was a primitive form of air conditioning, it is true, and somewhat later a humidifying sprayer was installed in the stacks, but the equipment could not cope with the greatly increasing dirt and harmful gases in the air.

\section{Houghton Library}

By 1940 the collections segregated in the Treasure Room numbered over one hundred thousand volumes and occupied portions of three levels of the Widener stacks. At that time an alumnus, Arthur Amory Houghton, Jr., by his understanding and munificence, made possible the erection of the Houghton Library for the care of the rare books and manuscripts of Harvard University, and the building was formally opened the end of February 1942.

Although, because of impending shortages, the construction was somewhat rushed, the general design and almost all the special features have proved their utility and practicability, so that there is very little that we now might prefer had been done differently. The dangers that have always been present in the minds of custodians of rare book collections have been provided against by, in some cases, novel methods. For example, since the building is of Class A construction throughout we are not much worried about fire. The danger of damage from water has been guarded against by reason of the inch and a half of cork and asphaltum which covers all outside walls, basement floor, and roof, while all horizontal runs of water pipes have beneath them wide copper trays which would both carry off the water from a leak and give warning of the fact that a leak had started. Trap doors have been provided at all turns in the pipes so that repair work can, if ever it should be needed, be carried out expeditiously.

Three of the six floors in the building are open to the public, but the stairs and doors are so arranged that all book storage parts of the building are separated from the public with a minimum of locked doors. The reading room, some thirty-five by fifty feet, has doors with electric locks, worked from the attendants' desk, which prevent a reader's leaving before his books have been returned. A guard stationed at the only public entrance examines all bags and may be warned from several parts of the building by means of a buzzer. We are now experimenting with invisible fluores- 
cent marking of the books and may soon be ready to give them that further protection against theft.

The specially designed shelves are of steel, with well-rounded edges and rubbed enamel several coats thick. They have no projecting screwheads or other sharp corners. We are as rapidly as possible putting fragile bindings in folding box-cases and we should have experimented with cushioned patent leather pads for working surfaces had not a war shortage prevented. We made our own book ends from cast concrete bricks covered with cardboard and buckram by the library bindery. They have been very satisfactory and there is no danger of their "knifing" a book. But careless handling is still a human matter and we are human.

\section{Air Conditioning}

The air conditioning arrangements have been in use now for two years and we have been able to observe how adequate they are both as recorded by the instruments and as they affect the books. The temperature throughout the year is a constant $70^{\circ}$, except on a few of the hottest days in summer when it may rise to $75^{\circ}$. The humidity is maintained at 50, except for a very few days in winter when it may drop to 45 or in summer when it may rise to 55 . During this past summer, however, it never rose above 52. Under such conditions even old cloth bindings seemed to regain their youth. The air is cleaned by a triple process of washing, filtering, and electrical precipitation, which while not perfect is very nearly so. The books do need occasional cleaning but not nearly so much as in former times. They are protected from the action of sunlight by reason of the fact that in those sections of the building where books are preserved very few windows are included.
This was done first of all because we wished to use all possible wall space for storage but also because with air conditioning windows were unnecessary and direct sunlight is notoriously injurious to bindings and paper.

\section{Exhibit Space}

Throughout the building the walls in all rooms open to the public have been utilized for the exhibition of book collections. A good deal of time and thought has been expended on the arrangement of these permanent exhibits, and after the war we expect to have an even more elaborate series of them than we now have. In the exhibition room proper, where our incunabula and medieval manuscripts are kept behind glass around the walls, we have provided special lighting in the form of Zylon tubes behind louver glass, so arranged that they do not heat the books but throw a soft light upon them without the source being evident. The exhibition cases are lighted in much the same way, and when tested with recording instruments the lights have failed to alter the temperature or humidity one degree.

Work space was provided for the staff of the present day, but it was planned that as our top floor is gradually opened up with rooms for special collections these rooms will be utilized as offices for various members of the staff, who will likewise supervise that part of the building when open to the public. Insofar as we have experimented with that method of housing the staff it appears that it will be practicable.

When the building was opened there was shelf room for a collection twice the size of that which was put in it. We had hoped that the provision of facilities to care for rare books properly would add to 


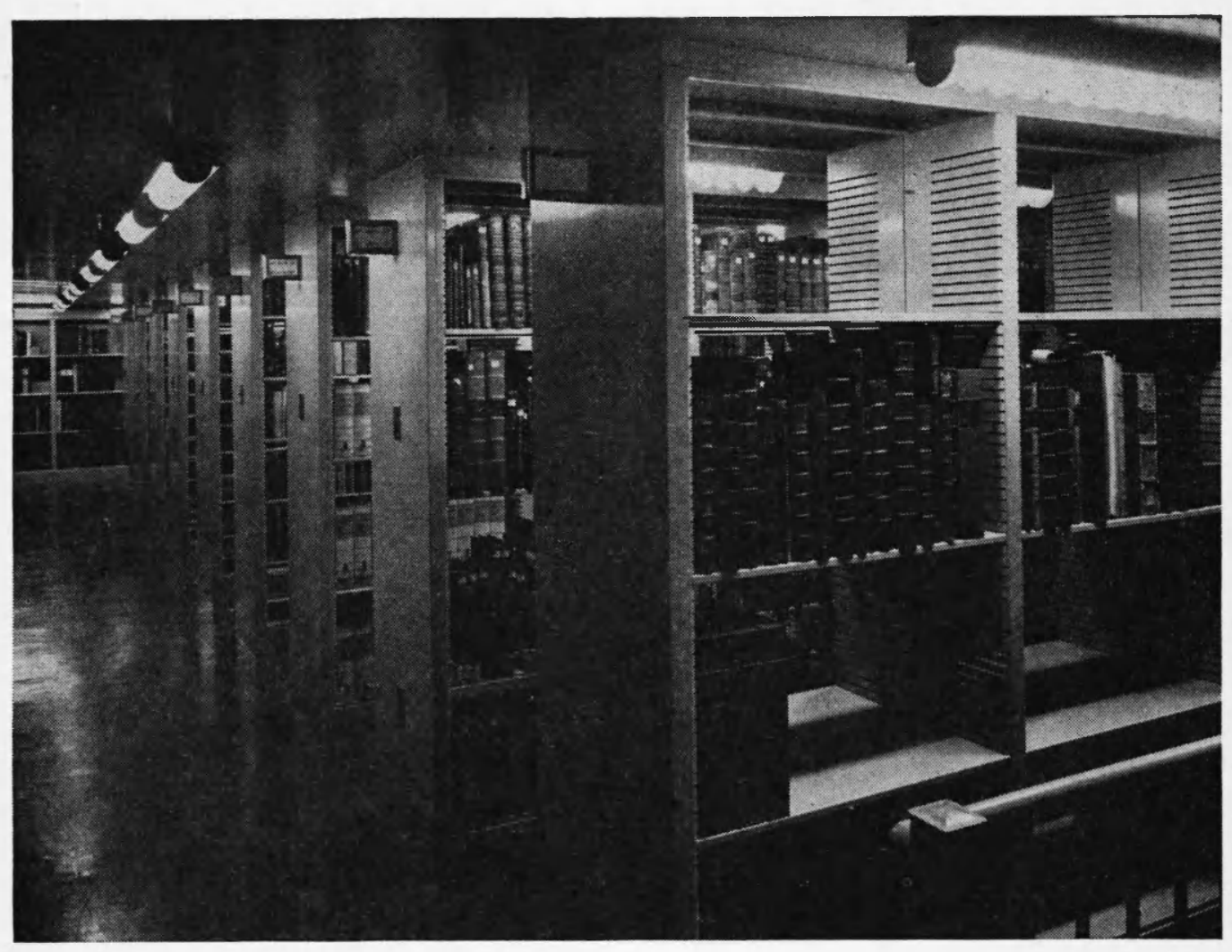

INTERIOR VIEW OF Houghton LibraRY

the number of gifts which we might receive. It is apparent that that has had a great influence upon the growth of the library, and it is not unlikely that the building will be filled within less than fifteen years. With that in mind, provision has been made in the foundations for pass- age to additional stacks to be built underground. If they should be called for in a few years, there will be many problems then to be solved, but their solution should be a happy burden, for it will mean that the collections are that much more useful and extensive. 